\title{
The Local Economic Impact of Universities: An International Comparative Analysis (France and Hungary)
}

\author{
Balázs Kotosz, Marie-France Gaunard-Anderson, and Miklós Lukovics
}

\section{Introduction}

Nowadays, the realization that certain economic units, universities, or other entities have an impact on the economy of their region has come more and more into prominence. A growing demand appears to generate more precise studies regarding the quantification of the economic impact of these entities. The topic of the examination of economic impact is especially interesting and exciting when we can compare regions with different levels of development, yet both with the presence of an internationally successful university (e.g. here the University of Lorraine in France and the University of Szeged in Hungary).

The roles of universities are also changing with time. As Wissema (2009) suggested, there are three generations of universities, while Pawlowski (2009) already mentioned fourth-generation universities. The characteristics of these universities are summarized in Table 1.

University generations are often mixed up with university missions, as education is considered the first mission, research the second, and developing the economy and enhancing competitiveness as the third mission (Zuti and Lukovics 2014).

The local economic impact of a large tertiary education institution such as a university is an issue which has attracted considerable attention in the literature. The different methods used in the literature make the results difficult to compare; we use the same method to investigate universities in different countries: lacking regional input-output matrices, a multiplier-based approach was used for the first and second missions (education and research).

B. Kotosz $(\triangle) \cdot$ M. Lukovics

University of Szeged, Szeged, Hungary

e-mail: kotosz@eco.u-szeged.hu

M.-F. Gaunard-Anderson

University of Lorraine, Metz, France 
Table 1 Characteristics of first-, second-, third-, and fourth-generation universities (based on Lukovics and Zuti 2013, 2014)

\begin{tabular}{l|l|l|l|l}
\hline Aspect & $\begin{array}{l}\text { First- } \\
\text { generation } \\
\text { universities }\end{array}$ & $\begin{array}{l}\text { Second- } \\
\text { generation } \\
\text { universities }\end{array}$ & $\begin{array}{l}\text { Third- } \\
\text { generation } \\
\text { universities }\end{array}$ & $\begin{array}{l}\text { Fourth-generation } \\
\text { universities }\end{array}$ \\
\hline Goal & Education & $\begin{array}{l}\text { Education } \\
\text { and research }\end{array}$ & $\begin{array}{l}\text { Education, } \\
\text { research, and } \\
\text { utilization of } \\
\text { knowledge }\end{array}$ & $\begin{array}{l}\text { Education, research, R+D+I, } \\
\text { utilization of knowledge, and } \\
\text { proactive economic } \\
\text { development }\end{array}$ \\
\hline Role & $\begin{array}{l}\text { Protection of } \\
\text { truth }\end{array}$ & $\begin{array}{l}\text { The cognition } \\
\text { of nature }\end{array}$ & $\begin{array}{l}\text { Creation of } \\
\text { added value }\end{array}$ & $\begin{array}{l}\text { Local economic accelerator, } \\
\text { strategy determination }\end{array}$ \\
\hline Output & Professionals & $\begin{array}{l}\text { Professionals } \\
\text { and scientists }\end{array}$ & $\begin{array}{l}\text { Professionals, } \\
\text { scientists, and } \\
\text { entrepreneurs }\end{array}$ & $\begin{array}{l}\text { Professionals, scientists, } \\
\text { entrepreneurs, and competi- } \\
\text { tive local economy }\end{array}$ \\
\hline Language & Latin & National & English & $\begin{array}{l}\text { Multilingual (national and } \\
\text { English) }\end{array}$ \\
\hline Management & Chancellor & $\begin{array}{l}\text { Part-time } \\
\text { scientists }\end{array}$ & $\begin{array}{l}\text { Professional } \\
\text { management }\end{array}$ & $\begin{array}{l}\text { Professional management } \\
\text { and local experts }\end{array}$ \\
\hline
\end{tabular}

Generally, there are four substantial problems in data collection and analysis. First, the definition of impact, second, measuring and estimating first-round expenditures and avoiding double counting, third, estimating the correct value of the multiplier, and fourth, the quantification of the third mission activities.

The economic impact study has become a standard tool used by Western universities to persuade state legislatures of the importance of expenditures on higher education. As economic impact studies become a political tool in the review of education, conservative assumptions and methods should be used to promote objectivity in the research process.

(Brown and Heaney 1997)

The main goal of this chapter is to compare the local economic impact of universities in two university towns, one in a relatively rich and the other in a relatively poor region of Europe. To avoid bias, we applied the same methodology based on the available data. As public universities guard their budget data as confidential information and do not permit outsiders to survey students, only the employers of the authors were possible targets of the research (see also Alves et al. 2015).

The structure of the chapter is the following. After this introduction, in the second part, we take a theoretical overview of the impact of universities. In the third part, we focus on measurement methods, solutions, and problems. The empirical evidence for the two universities is shown in Sect. 4, followed by a conclusion including a summary of open questions. 
Table 2 Classification of regional/local impacts of universities (Florax 1992; Garrido-Yserte and Gallo-Rivera 2010)

\begin{tabular}{l|l}
\hline Impact on & Example \\
\hline Politics & $\begin{array}{l}\text { Changes in the political structure, an increase in citizen participation, improve- } \\
\text { ment in the organization of political processes }\end{array}$ \\
\hline Demography & Impacts upon population growth, population structure, and mobility \\
\hline Economy & $\begin{array}{l}\text { Impacts upon regional/local income, industrial structure, job market, labour } \\
\text { mobility }\end{array}$ \\
\hline Infrastructure & Impacts upon housing, traffic, healthcare services, retail \\
\hline Culture & Greater offers in cultural goods, influence upon cultural environment \\
\hline Attractiveness & Influence upon the region's (local) image, regional (local) identity \\
\hline Education & Impact upon participation rate, changes in its quality \\
\hline Social aspects & $\begin{array}{l}\text { Impact upon the quality of life, the influence of the students, influence upon the } \\
\text { region's (local) image and regional (local) identity }\end{array}$ \\
\hline
\end{tabular}

\section{Theoretical Overview}

Beck et al. (1995) define economic impact as "the difference between existing economic activity in a region given the presence of the institution and the level that would have been present if the institution did not exist."

Florax (1992), and with modifications, Garrido-Yserte and Gallo-Rivera (2010), showed that the regional and local effects of a university can be observed in many fields beyond the economy (see Table 2).

Dusek (2003) sorts the impact into input and output side effects (with students on both sides, see Tables 3 and 4). He highlights the role of budget links as an important (economic) factor; the main financial source of the university is the government budget. These classifications are not far from the Segarra I Blasco (2004) model, who separated backward and forward effects. Among the forward effects are localization factors (instead of attractiveness), and he also mentions foreign investment and high-tech companies (that are typical actors of technopolis-type clusters).

Huggins and Cooke (1997) transferred the keywords into drivers and outcomes, and in their approach, one cannot find hard measures on the driver side, while there are hardly any soft outcomes.

Brown and Heaney (1997) concluded that the input size effects may be better measured than output side effects, while the third mission of universities, knowledge transfer, has mainly social impacts. Notwithstanding this, Beck et al. (1995) argue that social (human capital) factors must be heeded, unless the major part of impacts would not be incorporated. We agree that even if the volume of the third mission activities is difficult to recognize, the measurement of their impact on the local economy can be correctly arrived at only through complex dynamic economic models.

Pellenbarg (2005) modified Lambooy's table to achieve a complete list of economic impacts (see Table 5). However, this classification is a wide mixture of 
Table 3 Regional/local impacts of universities on the input side (Dusek 2003)

\begin{tabular}{l|l}
\hline Actor & Changes \\
\hline Households & + Income \\
& + Employment \\
& + Consumption \\
\hline Local authority & + Tax base \\
& + Services \\
\hline Business & + Volume of business \\
\hline
\end{tabular}

Table 4 Regional/local impacts of universities on the output side (Dusek and Kovács 2009)

\begin{tabular}{l|l}
\hline Factor & Changes \\
\hline Human capital & $\begin{array}{l}\text { + Qualification } \\
\text { + New firms } \\
\text { + Migration }\end{array}$ \\
\hline Knowledge & $\begin{array}{l}\text { + University-business relations } \\
\text { + Extensive use of resources }\end{array}$ \\
\hline Attractiveness & $\begin{array}{l}\text { + Location choice of households and firms } \\
\text { + Cultural and social possibilities }\end{array}$ \\
\hline Business & + Research and development, exhibitions \\
\hline
\end{tabular}

Table 5 Regional/local economic impacts of universities (Pellenbarg 2005)

\begin{tabular}{l|l}
\hline $\begin{array}{l}\text { Economic impacts of a } \\
\text { university }\end{array}$ & Example \\
\hline $\begin{array}{l}\text { Employment at the } \\
\text { university }\end{array}$ & $\begin{array}{l}\text { The number of university jobs } \\
\text { and related institutions }\end{array}$ \\
\hline University income & $\begin{array}{l}\text { State contributions, fees, benefits } \\
\text { arising from entrepreneur } \\
\text { activity, etc. }\end{array}$ \\
\hline University expenditure & $\begin{array}{l}\text { Purchase of goods and services } \\
\text { by the university }\end{array}$ \\
\hline $\begin{array}{l}\text { Income and expenditures of } \\
\text { the university employees }\end{array}$ & $\begin{array}{l}\text { Wages and salaries, social } \\
\text { security costs }\end{array}$ \\
\hline Effects on the job market & $\begin{array}{l}\text { Qualified job provision effect } \\
\text { upon productivity; flexible } \\
\text { workforce supply of the students }\end{array}$ \\
\hline Generation of business & $\begin{array}{l}\text { Companies created by university } \\
\text { students and employees, with or } \\
\text { without employment knowledge } \\
\text { and technology }\end{array}$ \\
\hline Knowledge marketing & $\begin{array}{l}\text { The sale of knowledge in a } \\
\text { variety of ways: from ideas, } \\
\text { courses, and patents }\end{array}$ \\
\hline
\end{tabular}

impacts of the three main missions of universities (education, research, and university-enterprise cooperation) and has many doubly counted factors.

Lengyel (2008) gives a more complex system of economic effects, including many elements of the previous literature (see Fig. 1). 


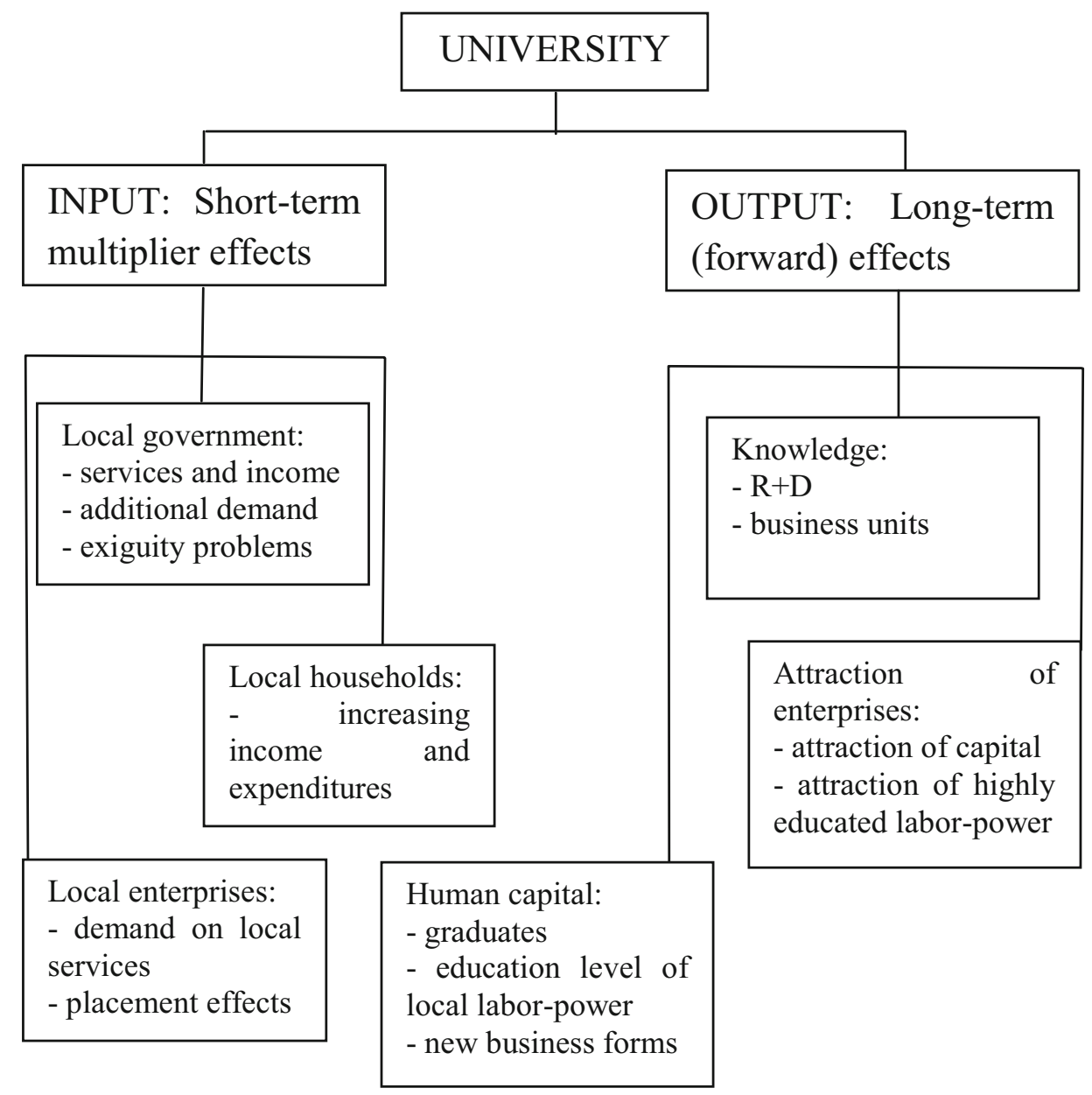

Fig. 1 Local economic effects of universities. Source: Lengyel (2008)

Table 6 Classification of the economic impacts of the universities (Garrido-Yserte and GalloRivera 2010)

\begin{tabular}{l|l|l|l}
\hline $\begin{array}{l}\text { Impacts } \\
\text { upon }\end{array}$ & Short term & Long term \\
\hline Expenditures & $\begin{array}{l}\text { Increase of the regional GDP } \\
\text { Salaries } \\
\text { Employment } \\
\text { Taxes }\end{array}$ & $\begin{array}{l}\text { Steady increase of regional GDP } \\
\text { Investments on equipment }\end{array}$ & \multicolumn{2}{|l}{} \\
\hline Knowledge & $\begin{array}{l}\text { Changes in the job market } \\
\text { Development of human } \\
\text { capital }\end{array}$ & $\begin{array}{l}\text { Subjective } \\
\text { Externalities } \\
\text { Workers' productivity } \\
\text { Increase of income throughout } \\
\text { life }\end{array}$ & $\begin{array}{l}\text { Objective } \\
\text { Patents } \\
\text { Research } \\
\text { and } \\
\text { development }\end{array}$ \\
\hline
\end{tabular}

Garrido-Yserte and Gallo-Rivera (2010) also attached importance to the separation of short- and long-term effects and constructed a matrix of impacts (see Table 6). This version is the most complex rethinking of impacts and consideration of the economic impact of originally social phenomena. 
Brown and Heaney (1997) compare two approaches to the computation: the skillbased approach and the economic-based approach. These approaches are close to the logic of the knowledge- and expenditures-based classification.

Johnson (1994) argues for separating local and non-local (determined by the choice of territorial scope), direct and indirect impacts (see later), but he also attends to various negative impacts of universities and to the necessity of a net approach (i.e. individuals could spend more if the government did not tax them to be able to pay the expenditures of universities - the double net question would be that people from somewhere are taxed to pay the expenditures of the given university). The question of gross or net impact can be analysed from many starting points. Generally, gross impact is easier to define and compute, as such questions arise in case of the lack of the university:

- What and where the staff would work,

- Where would students would pursue their studies (if at all),

- How large would the difference of knowledge in the local economy would be

- What would be the difference in housing prices?

We cannot forget that these questions are also linked to the choice of territorial level. The process can be observed when newly founded universities are investigated: e.g. most of the academic staff is coming from other (national) universities, while non-academic staff can be hired locally. Local housing prices change slowly, so only a complex comparative analysis (e.g. a panel regression analysis) can detect the differences due to the presence of a university.

The classification of impacts from the point of view of how directly the impact is related to the activity of the university is widely varied in the literature. We can find twofold, threefold, and fourfold classifications. The common point is the separation of direct and indirect impacts, where direct impacts include the expenditures of the university, the staff, and the students. In a larger classification, we have induced impacts (Klophaus 2008), while in the fourfold version, one can also find catalytic impacts [for these impacts, see Lukovics and Dusek (2014a, b) for university-related research, or Dusek and Lukovics (2011) for business service]. The modified version of these classifications (see Fig. 2) represents the impacts of universities as:

- Direct impact: output, income, and workplaces created on-site owing to the investments and operation of the university

- Indirect impact: income and employment generated in the companies providing inputs for the university

- Induced impact: income and employment generated with the multiplier impact owing to spending the incomes

- Catalytic impact: productivity growth achieved through the operation of the university, the income and employment created through the companies settling because of the university, and the spending of the visitors arriving because of the university

The contradictory and sometimes misleading mélange of the impacts can be well shown by juxtaposing (see Table 7) those of the Garrido-Yserte and Gallo-Rivera (2010) 


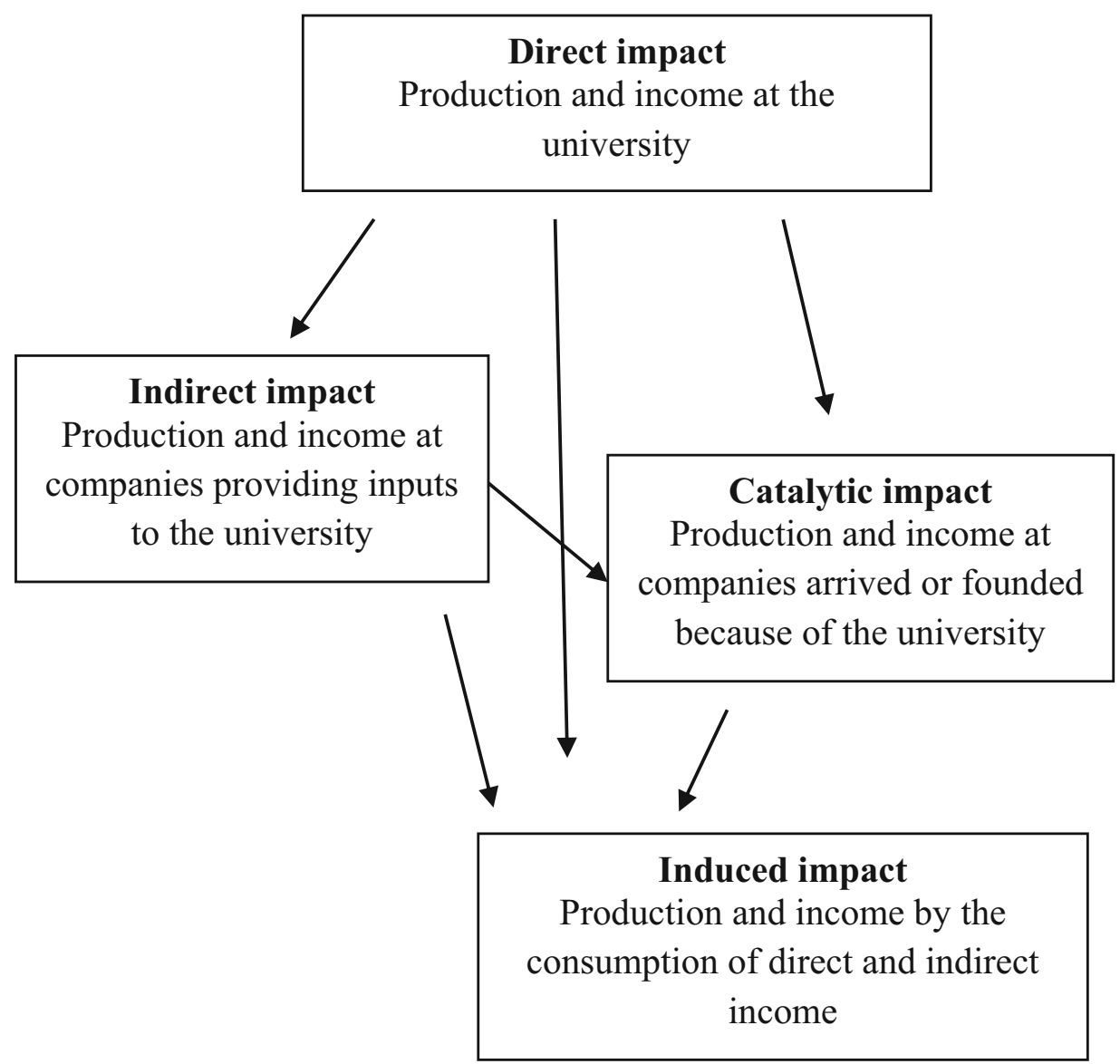

Fig. 2 Direct, indirect, induced, and catalytic effects. Source: Based on the idea of Dusek and Lukovics (2011)

Table 7 Regional/local economic impacts of universities (Garrido-Yserte and Gallo-Rivera 2010; Gagnol and Héraud 2001)

\begin{tabular}{|c|c|c|}
\hline \multirow[b]{2}{*}{ Impact } & \multicolumn{2}{|l|}{ Meaning } \\
\hline & Garrido-Yserte-Gallo-Rivera & Gagnol-Héraud \\
\hline Direct & $\begin{array}{l}\text { Related to the local expenditures of the } \\
\text { university, staff, and students of the } \\
\text { university }\end{array}$ & $\begin{array}{l}\text { Consumption of the university, staff, and } \\
\text { students of the university }\end{array}$ \\
\hline Indirect & $\begin{array}{l}\text { Multiplied income (each euro spent at the } \\
\text { location by the university community } \\
\text { (university, staff, and students) generates } \\
\text { indirect transactions in the location linked } \\
\text { to businesses that do not have a direct } \\
\text { relation to the university }\end{array}$ & $\begin{array}{l}\text { Impact through education of the work- } \\
\text { force, development of synergies of } R \& D \\
\text { with regional enterprises }\end{array}$ \\
\hline Induced & $\begin{array}{l}\text { The expenditures of the people that visit } \\
\text { the university, the effects upon financial } \\
\text { institutions, the effects upon property } \\
\text { value, and the impact upon location of new } \\
\text { companies and so on }\end{array}$ & Multiplier effect \\
\hline
\end{tabular}


and the French school represented by Gagnol and Héraud (2001) and Baslé and Le Boulch (1999).

In this confusion, we would recommend using induced impact for all effects that are generated by the multiplication process. In the Lukovics and Dusek classification, the separation of direct and indirect impacts is artificial (practically, we separate personal expenses from the purchase of assets and investment due to the local analysis: on-site created income is always local-nevertheless, not necessary locally spent). Thereby, the primary expression for direct and indirect impacts would be better established. The catalytic impact of Lukovics and Dusek, the indirect impact of Gagnol and Héraud, and the induced impact of Garrido-Yserte and Gallo-Rivera have almost the same content. While it is not widespread in the literature, the catalytic expression better describes the content of this category than indirect or induced (induced seeming to be the worst choice).

\section{Methodology}

The main methodological possibilities are the use of input/output matrix-based models or the Keynesian multiplier model family. As up-to-date local or at least regional level input/output matrices are not available (neither for France, nor for Hungary), we could not use the first type of models. The use of such models is typical in the USA where such matrices are accessible at the state level, but these models have a territorial scope at this level.

The territorial scope of our analysis was local. In Szeged, the university is dominantly in the city (with one small faculty outside the city), in France we had the possibility for the survey only in Metz, and so a regional estimation of the impact of one campus would not be meaningful. Using a larger territorial scope would increase the absolute gross impact, but per capita or per GDP impact may be smaller.

Whenever it was possible, we used data for 2014.

In Bleaney et al. (1992), we can find a mathematical deduction of the formula of the Keynesian regional multiplier. This method is the most often used one for computation, with a series of disadvantages and deficiencies. Its simplicity makes it so popular, as a relatively narrow scale of data is necessary. In our comparison, we will follow a version of the regional multiplier model. The method we applied in Figs. 3 and 4 is a modification of the Caffrey and Isaacs (1971) and Bridge (2005) models, which we can also call a simplified ACE model in the terminology of Garrido-Yserte and Gallo-Rivera. The original Bleaney model was modified at two points: (1) we use and apply local consumption habits (with a rough estimation of local marginal propensity to consume) and (2) we calculate primary production and consumption effect in two steps. The latter methodological background is described in Felsenstein (1995).

In our chapter, we followed the computations made in our earlier work (see Kotosz 2013 or Zuti and Lukovics 2015), using the same methodology, model, and primary research agenda, so our results are fully comparable. 
University incomes

Government (183 M EUR)

Operation income (47 M EUR)

non-profit

institutions

charity

(terminal) fees

adventure income

foreign assistance

capital income

other

\section{Local economy}

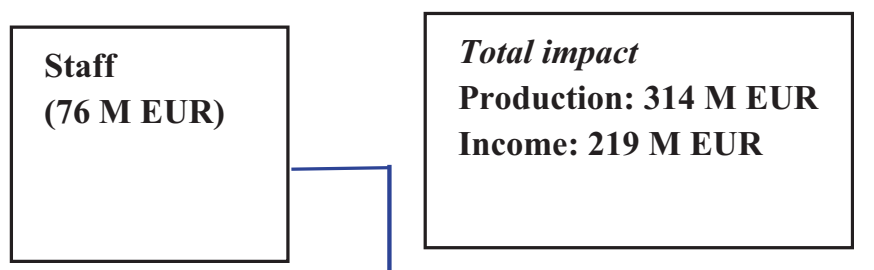
production and income effect

\section{University expenses}

Staff costs (97 M EUR)

Material type and operating costs, and investment (121 M EUR)

Fellowships and other grants (9 M EUR)

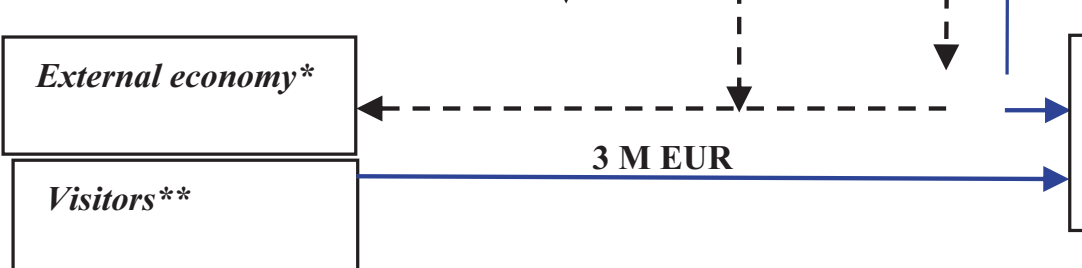

Primary effect

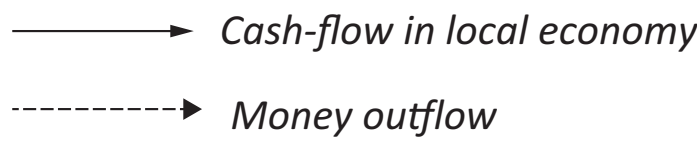

\section{* Non-local economy \\ ** Expenses of visitors}

Fig. 3 Cash flow in Szeged

The multiplication effect is the function of the following factors:

- Personal income tax rate (average rate) [t]

- Value-added tax (average rate) [n]

- Marginal propensity to consume [c]

- Local consumption proportion of students [d]

- Local consumption proportion of employees [e]

- Local consumption proportion of the university [b]

- Local consumption proportion of the local economy [f] 
University incomes

Government (112 M EUR)

Operation income (11 M EUR)

non-profit

institutions

charity

(terminal) fees

adventure income

abroad assistance

capital income

other

\section{Local economy}

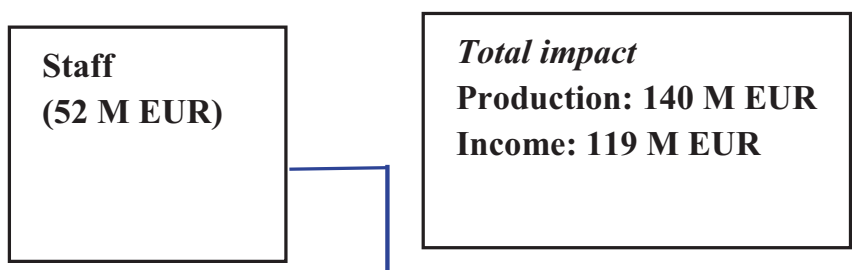

Primary production and income effect

\section{University expenses}

Staff costs (90 M EUR)

Material type and operating costs, and investment (33 M EUR)

Fellowships and other grants (1 M EUR)

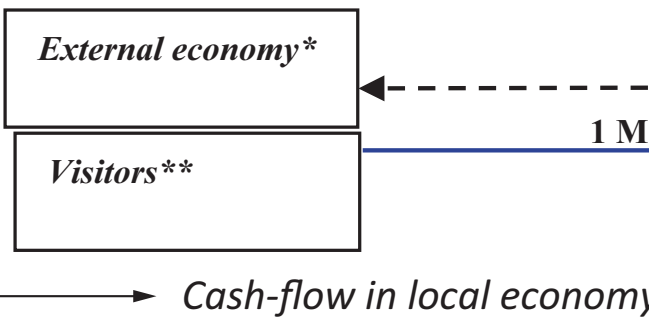

\section{Money outflow}

* Non-local economy

** Expenses of visitors

Fig. 4 Cash flow in Metz

Armstrong and Taylor (2000) and Lengyel and Rechnitzer (2004) supposed a fixed amount of spending of visitors and an equivalent local consumption proportion of students, employees, and the university. Instead of this, we applied a two-step estimation, so different proportions could be used. Thereby the formula of the multiplier is: 


$$
\frac{1}{1-f \cdot c \cdot(1-t) \cdot(1-n)}
$$

Expenditure data of the universities can be accessed from public information (profit and loss statements). In the case of multi-campus institutions, the allocation of expenditures by campus has been based on our estimation (when expenditures cannot be definitely allocated, we used keys related to relevant activities: the number of students, number of academic/non-academic staff, area, etc.). We supposed that employees have an additional income of $20 \%$ over their salary at the university. Estimation of visitors' expenditures is based on conferences and other events attracting visitors. Otherwise, visitors barely affect the total economic effect.

To map expenditures of students, we asked them to fill in a questionnaire (in 2014 in Szeged, and in 2015 in Metz). This element was based on a representative sample, and we multiplied the sample mean by the number of students enrolled at the university/campus.

To estimate the locally valid consumption function, we can follow two different paths. From one part, we can use national statistics, as from empirical evidence (see Árvay and Menczel 2001; Vidor 2005) local and national functions are not significantly different. From the other part, local sample surveys can also serve as a starting point. Our computations also showed that national or regional crosssectional and time series data give largely different results, between 0.45 and 0.7 in both countries. We have local, survey-based results only for students. While Dusek (2003) found a high marginal propensity to consume in his survey of students (over 0.7), our results in Hungary are below 0.5, while in France it is around 0.5. In the model, we use a unique marginal propensity to consume, and we applied the most reliable national and regional estimations with a consensus value of 0.6.

The lack of reliable geographical knowledge of students (in many cases, they did not know in which county the university was operating) moved us to choose the local level as the city where the university is located (Szeged and Metz). By extending the geographical area, the local consumption ratio increases but not proportionally with distance.

The local consumption proportion of students varied around 70-80\% based on our survey data (in accordance with previous data from other surveys). This number is always higher than the rate of local students, which is around $30-40 \%$. In our estimations, we used the value of 0.7 in Metz, and 0.8 in Szeged, as the results of the surveys.

The estimation of employees' local consumption proportion is one of the most problematic points of the process, as in neither city did we have the right to ask employees via a questionnaire similar to students' questionnaire. As a result of the suburbanization process, we supposed that the local consumption proportion is lower than the students', and we used 75\% in Szeged, but only 60\% in Metz.

The local consumption proportion of public universities in Europe is typically determined and restricted by national law. Well-known estimation problems arise with the limitation of the local level (see Székely 2013), but this question is beyond the goals of the chapter. We analysed the official documents of the universities and 
estimated these impacts by separating local and non-local items. We used a $70 \%$ value for Szeged and $80 \%$ for Metz.

For the average tax rates, we used recent estimations of the Hungarian National Bank for Hungary and Ministry of Finance data for France. While average VAT rates are similar (16\% in France, and 20\% in Hungary), the NUTS3 level average personal income tax rate is only $6 \%$ in Lorraine, while the national rate of Hungary was $20.1 \%$ (for the methodology, see Benczúr and Kátay 2010). This difference can be explained by the inclusion of some social security contributions.

Generally, in scientific papers on impact studies, there are detailed theoretical comparisons of previously applied methods, but we cannot find international comparative studies where invariable methods have been used. Even with this deficiency, we can internationally compare the impact of the analysed universities.

\section{Empirical Evidence and Results}

Even if the theoretical background is not uniform, but well known, estimation methods are carefully done and discussed (see Siegfried et al. 2006 for a general comparison), and many international empirical examples can be found in the literature (Armstrong 1993; Blackwell et al. 2002; Bleaney et al. 1992; Bridge 2005; Brownigg 1973; Caroll and Smith 2006; Cooke 1970; Huggins and Cooke 1997; Jabalameli et al. 2010; Lewis 1988; Love and McNicoll 1988; Ohme 2003; Pellenbarg 2005; Robert and Cooke 1997; Simha 2005; Tavoletti 2007), yet until 2010 only one finished case study was known for Hungary, the case of the university of Gyôr (Széchenyi István University) (Dusek and Kovács 2009). Some steps were also made in Pécs (Mezei 2005), but this research has not reached the level of having at least one numerical result. An intensive phase of research started after 2010, the first results having been published in Kotosz $(2012,2013)$ for small colleges, and in Zuti and Lukovics (2015) for the University of Szeged. In Dusek and Lukovics (2014), we can also find an example impact study of a research-oriented future entity.

In France, three scientific impact studies are known, the case of Strasbourg (Gagnol and Héraud 2001), Rennes (Baslé and Le Boulch 1999), and the University of Littoral (Mille 2004). These papers can only partially handle the questions, not having an expressed number of euros (francs) as impact (except for Baslé and Le Boulch 1999 where multiplier effects are also determined).

The higher education systems in the two countries are similar in the sense that originally they are based on state-owned/state-financed universities, complemented by smaller private schools where education is more accentuated than research. Due to the Soviet heritage in Hungary, an independent (from universities) academic research centre network has survived. In France, research centres are more integrated in the universities, often creating a matrix system of education and research. Education divisions may run under different names (faculties, education and research units, institutes). While in the Hungarian system faculty positions are also divided between 
lecturers and researchers, in France academic staff members are lecturer-researchers. These characteristics do not help the separation of education and research-related expenditures and incomes.

Higher education in Hungary went through significant changes in the 1990s, which on the whole had an impact on the entire Hungarian society. Since the regime change, the number of students has risen significantly, nearly quadrupling. This tendency was noticeable both in the OECD and in the EU countries over a longer period. However, in Hungary after the 2005/2006 academic year, a decrease is perceptible regarding the number of students. On the basis of 2008 data, Hungary lags behind all examined OECD countries concerning the number of state-funded students per million inhabitants. While this data in Hungary was 21,324 per million, in Germany it was 24,639, in Austria 28,974, and in Norway 38,409 per million (Harsányi and Vincze 2012). From the perspective of our study, it is essential to review the Hungarian higher education's system of institutions. Since 2011, in Hungary the administration of higher educational institutions has transformed appreciably, and with this the organizational and administrational autonomy of the institutions, too. First, the appointment of rectors and economic directors has come under the authority of the ministry, and after that, budget commissioners were ordered to the institutions. In 2014, the chancellery system was implemented.

The French higher education system did not experience such shocks, and the number of students has had a growing trend with more than 2.4 million students in 2014. The significantly higher wage level in France can be observed in the dominancy of personnel costs in the budget of public universities.

The University of Szeged was founded in 1872 and has about 25,000 students and 12 faculties. After various historic events, in 2000 it unified almost all faculties working in the city. The Faculty of Medicine integrates a clinical centre (hospital) with activities that cannot be separated (financially) from the university. Szeged has around 170,000 inhabitants in a region which is among the 20 poorest regions of the European Union (measured in per capita GDP).

The first university in Metz was founded in 1970 based on smaller higher education institutions already existing in the city. In 2012, the universities of the Lorraine region were unified to create the University of Lorraine, which is the second largest university of France (by the number of students). The university has more than 50,000 students, 13,000 of them located in Metz, where 6 faculties can be recognized. As our research concerns only the city of Metz, university budget items had to be divided by keys. The city of Metz has about 120,000 inhabitants, in a region less developed than the French average (but over the EU average).

A summary of indicators of the two territories can be found in Table 8 .

The main findings of our research for Szeged and Metz can be summarized in Figs. 3 and 4, respectively.

These flowcharts display the main financial information of the universities, including the incomes and expenditures of the universities. While the amount of staff costs is equivalent at the two universities, in Szeged more is spent on investment and material costs (due to wage level differences in the two countries). Major differences can also be observed in the case of students' spending; the more local 
Table 8 Main indicators of the territories in the study (based on the different statistical data of the French and Hungarian statistical offices and OECD Statistics for 2014, persons in thousands)

\begin{tabular}{l|l|l}
\hline Measure & Metz & Szeged \\
\hline Region NUTS 2 & Lorraine & Dél-Alföld \\
\hline Region NUTS 3 & Moselle & Csongrád \\
\hline Number of inhabitants in the city & 120 & 163 \\
\hline Number of inhabitants in the NUTS 3 region & 1045 & 406 \\
\hline Number of faculties at the university & 10 & 12 \\
\hline Number of companies & 29,200 & 13,700 \\
\hline Number of employees (at NUTS 3 level) & 212 & 173 \\
\hline GDP per capita in PPP (2013) & 27,400 & 15,000 \\
\hline
\end{tabular}

attraction zone of the French institution caused important differences (housing costs are the most important costs for students, but if they live with their parents, it is considered zero). The strong international characteristic of the University of Szeged resulted in higher visitor income, while the disparity of the regional multiplier has been explained earlier by different tax rates.

\section{Conclusion}

In the level of comparable results, we can analyse the impact per student or the impact per regional GDP.

The total impact per student is in the range of 15-50 thousand euros in the USA and in the range of 10-20 thousand euros in Western Europe, while between 5 and 10 thousand euros in Eastern Europe by benchmark studies. For a detailed comparison of benchmark studies, see Kotosz and Lukovics (2017). The results of around 11 thousand euros in our target cities can be explained by the fact that the University of Szeged has a clinical centre where medical activities require greater expenditures than education and-non-clinical—research of the whole university.

In the percentage of the regional GDP, the impact in the USA is generally in the range of $0.1-3.0 \%$, while in Europe only $0.02-0.10 \%$. Our results of $4 \%$ in Szeged and $0.02 \%$ in Metz are extremes. This difference can be explained by three facts: First, the presence of the medical centre in Szeged (four times higher impact); second, the difference of regional GDP (eight times higher impact); and third, we investigated a local campus in Metz, yet the whole university in Szeged (five times higher impact). The deviation is not methodology dependent; if we could find appropriate data for input-output matrix-based analysis, it would endure.

It is important to see that the direct and multiplied (induced) income impacts of these universities are in the order of the sum of money invested by different levels of government. Thereby, their third mission activities and/or catalytic impacts are crucial in their local/regional added value (Jongbloed 2008). It has been proven by Varga (2001) that agglomeration matters; the impact of third mission activities is 
larger in large universities than it could be explained by their relative size. However, the estimation of the impact of third mission activities is not developed in the literature. The intensity of these activities can be measured by a set of indicators, but it is not clear how we can turn these numbers to euros of economic impact.

\section{References}

Alves, J., Carvalho, L., Carvalho, R., Correia, F., Cunha, J., Farinha, L., Fernandes, J., Ferreira, M., Lucas, E., Mourato, J., Nicolau, A., Nunes, S., Nunes, S., Oliveira, P., Pereira, C., Pinto, S., \& Silva, J. (2015). The impact of polytechnic institutes on the local economy. Tertiary Education and Management, (2), 1-18.

Armstrong, H. W. (1993). The local income and employment impact of Lancaster University. Urban Studies, 30, 1653-1668.

Armstrong, H. W., \& Taylor, J. (2000). Regional economics and policy. Oxford: Blackwell.

Árvay, Z., \& Menczel, P. (2001). A magyar háztartások megtakarításai 1995 és 2000 között. Közgazdasági Szemle, 47, 93-113.

Baslé, M., \& Le Boulch, J.-L. (1999). L'impact économique de l'enseignement supérieur et de la recherche publique sur une agglomération de Rennes. Revue d'Economie Régionale \& Urbaine, $1,115-134$.

Beck, R., Elliott, D., Meisel, J., \& Wagner, M. (1995). Economic impact studies of regional public colleges and universities. Growth and Change, 245-260.

Benczúr, P., \& Kátay, G. (2010). Adóreformok hatása a magyar gazdaságra egy általános egyensúlyi modellben. Accessed March 24, 2011, from http://media.coauthors.net/konferencia/conferences/ 3/benczur_katay.pdf

Blackwell, M., Cobb, S., \& Weinberg, D. (2002). The economic impact of educational institutions: Issues and methodology. Economic Development Quarterly, 16(1), 88-95.

Bleaney, M. F., Binks, M. R., Greenaway, D., Reed, G., \& Whynes, D. K. (1992). What does a university add to its local economy? Applied Economics, 24, 305-311.

Bridge, M. (2005). Higher education economic impact studies: Accurate measures of economic impact? Journal of College Teaching and Learning, 2, 37-47.

Brown, K. H., \& Heaney, M. T. (1997). A note on measuring the economic impact of institutions of higher education. Research in Higher Education, 38(2), 229-240.

Brownigg, M. (1973). The economic impact of a new university. Scottish Journal of Political Economy, 20, 123-129.

Caffrey, J., \& Isaacs, H. H. (1971). Estimating the impact of a College or University on the Local Economy. Washington: American Council on Education.

Caroll, M. C., \& Smith, B. W. (2006). Estimating the economic impact of universities: The case of bowling Green State University. The Industrial Geographer, 3(2), 1-12.

Cooke, E. (1970). Analysing university student contribution to the economic base of the community. Annals of Regional Science, 4, 146-153.

Dusek, T. (2003). A felsôoktatás lokális termelésre és jövedelmekre gyakorolt hatása. In J. Rechnitzer \& T. Hardi (Eds.), A Széchenyi István Egyetem hatása a régió fejlódésére (pp. 60-71). Gyốr: Széchenyi István Egyetem Gazdaság- és Társadalomtudományi Intézet.

Dusek, T., \& Kovács, N. (2009). A Széchenyi István Egyetem hatása a helyi munkaerópiacra. In A Virtuális Intézet Közép-Európa Kutatására VIKEK Évkönyve, II (pp. 69-73). Régiók a Kárpátmedencén innen és túl konferencia tanulmányai, VIKEK, Szeged.

Dusek, T., \& Lukovics, M. (2011). Analysis of the economic impact of the Budapest Airport on the local economy. 58th Annual North American Meetings of the Regional Science Association International (RSAI). RSAI, Miami, 9-11 November 2011. 
Dusek, T., \& Lukovics, M. (2014). Az ELI és az ELI Science Park gazdasági hatásvizsgálata. Területi statisztika, 5, 1-18.

Felsenstein, D. (1995). Dealing with induced migration in university impact studies. Research in Higher Education, 36, 457-472.

Florax, R. (1992). The university: A regional booster? Aldershot, UK: Avebury.

Gagnol, L., \& Héraud, J.-A. (2001). Impact économique régional d'un pôle universitaire : Application au cas strasbourgeois. Revue d'Economie Régionale \& Urbaine, 2001(4), 581-604.

Garrido-Yserte, R., \& Gallo-Rivera, M. T. (2010). The impact of the university upon local economy: Three methods to estimate demand-side effects. Annals of Regional Science, 44, 39-67.

Harsányi, G., \& Vincze, S. (2012). A magyar felsőoktatás néhány jellemzóje nemzetközi tükörben. Pénzügyi Szemle, 2012(2), 226-245.

Huggins, R., \& Cooke, P. (1997). The economic impact of Cardiff University: Innovation, learning and job generation. GeoJournal, 41(4), 325-337.

Jabalameli, F., Ahrari, M., \& Khandan, M. (2010). The economic impact of University of Tehran on the Tehran district economy. European Journal of Social Sciences, 13(4), 643-652.

Johnson, T. M. (1994). Estimating the economic impact of a college or university on a nonlocal economy. $\mathrm{PhD}$ dissertation, Texas Tech University, Texas.

Jongbloed, B. (2008). Indicators for mapping university-regional interactions. In: Paper for the ENID-PRIME Indicators Conference in Oslo, 26-28 May 2008.

Klophaus, R. (2008). The impact of additional passengers on airport employment: The case of German airports. Airport Management, 2, 265-274.

Kotosz, B. (2012). Felsőoktatási intézmények regionális multiplikátor hatása. Jelenkori társadalmi és gazdasági folyamatok, 7(1-2), 7.

Kotosz, B. (2013). Local economic impact of universities. Analecta Technica Szegedinensia, 2013 (1-2), 22-26.

Kotosz, B., \& Lukovics, M. (2017). Az egyetemek helyi gazdasági hatásainak mérése. Saarbrücken: GlobeEdit.

Lengyel, I. (2008). “Távolság versus közelség” dilemma az ipari-egyetemi kapcsolatokon alapuló tudásalapú helyi gazdaságfejlesztésben. In A gazdasági környezet és a vállalati stratégiák (pp. 551-562). A IX. Ipar- es Vállalatgazdasági Konferencia előadásai, Szeged.

Lengyel, I., \& Rechnitzer, J. (2004). Regionális gazdaságtan. Budapest-Pécs: Dialóg-Campus.

Lewis, J. A. (1988). Assessing the effect of the polytechnic, Wolverhampton on the local community. Urban Studies, 25, 25-31.

Love, J. H., \& McNicoll, I. H. (1988). The regional economic impact of overseas students in the UK: A case study of three Scottish universities. Regional Studies, 22, 11-18.

Lukovics, M., \& Dusek, T. (2014a). Economic impact analysis of the ELI R\&D infrastructure and science park. Journal Mittelforum and Next Europe, 1, 72-85.

Lukovics, M., \& Dusek, T. (2014b). The economic impact of the ELI R\&D infrastructure and science park in the Szeged sub-region. Diverse regions: Building resilient communities and territories. Regional Studies Association Annual International Conference 2014, Izmir, Turkey.

Lukovics, M., \& Zuti, B. (2013). Successful universities towards the improvement of regional competitiveness: "Fourth Generation" universities. In European Regional Science Association (ERSA) 53th Congress "Regional Integration: Europe, the Mediterranean and the World economy”, European Regional Science Association, Palermo, 27-31 August 2013.

Lukovics, M., \& Zuti, B. (2014). Egyetemek a régiók versenyképességének javításáért: "negyedik generációs" egyetemek? Tér és Társadalom, 4, 77-96.

Mezei, K. (2005). A Pécsi Tudományegyetem hatása a város gazdaságára. A magyar városok kulturális gazdasága. Budapest: MTA Társadalomkutató Központ.

Mille, M. (2004). Université, externalités de connaissance et développement local: l'expérience d'une université nouvelle. Politiques et gestion de l'enseignement supérieur, 16(3), 89-113.

Ohme, A. M. (2003). The economic impact of a university on its community and state: Examining trends four years later. mimeo: University of Delaware. 
Pawlowski, K. (2009). The 'fourth generation university' as a creator of the local and regional development. Higher Education in Europe, (1), 51-64.

Pellenbarg, P. H. (2005). How to calculate the impact of university on the regional economy. In Conference on Knowledge and Regional Economic Development, Barcelona, 9-11 June 2005.

Robert, H., \& Cooke, P. (1997). The economic impact of Cardiff University: Innovation, learning and job generation. GeoJournal, 41(4), 325-337.

Segarra I Blasco, A. (2004). La universitat com a instrument de dinamització socioconómica del territori. Coneixement i Societat, 3, 78-101.

Siegfried, J. J., Sanderson, A. R., \& McHenry, P. (2006). The economic impact of colleges and universities (Vanderbuilt University Working Paper No 06-W12).

Simha, O. R. (2005). The economic impact of eight research universities on the Boston region. Tertiary Education and Management, 11, 269-278.

Székely, A. (2013). Regionális multiplikáció a szegedi Árkád példáján. In J. Rechnitzer, P. E. Somlyódiné, \& G. Kovács (Eds.), A hely szelleme - a területi fejlesztések lokális dimenziói (pp. 565-573). Gyớr: Széchenyi István Egyetem.

Tavoletti, E. (2007). Assessing the regional economic impact of higher education institutions: An application to the University of Cardiff. Transition Studies Review, 14(3), 507-522.

Varga, A. (2001). Universities and regional economic development: Does agglomeration matter? In B. Johannson, C. Karlsson, \& R. Stough (Eds.), Theories of endogenous regional growth. Berlin: Springer.

Vidor, A. (2005). A megtakarítás-ösztönzók hatása: magyarországi tapasztalatok. PM Kutatási Füzetek. Accessed October 13, 2010, from http://www2.pm.gov.hu/

Wissema, J. G. (2009). Towards the third generation university: Managing the university in transition. Cheltenham: Edward Elgar.

Zuti, B., \& Lukovics, M. (2014). "Fourth generation" universities and regional development. In R. Hamm \& J Kopper (Eds.), Higher education institutions and regional development (pp. 14-31). Mönchengladbach.

Zuti, B., \& Lukovics, M. (2015). How to measure the local economic impact of the universities' third mission activities? In P. Nijkamp, K. Kourtit, M. Buček, \& O. Hudec (Eds.), 5th Central European Conference in Regional Science (pp. 1209-1215). Technical University of Košice, Košice. 